\title{
Some Highlights in the Popular Clothes Market in Aprazível, Sobral-Ce
}

\author{
Ítalo Ramon Sales Silva ${ }^{1}$ \\ Luiz Antônio Araújo Gonçalves ${ }^{2}$
}

\begin{abstract}
This manuscript focus on some aspects related to the dynamics of the clothes street market in Aprazivel (Sobral, $C E)$, from the products to the labor sold and carried out. Together, they contribute to the discussion and debate on this productive activity that generates employment and income for the inhabitants of Aprazivel. As a consequence, it influences the regional economy in the northwestern Ceará. The methodological procedures were the literature review and fieldwork, carried out at the beginning of 2020, which gathered information regarding the conditions of the clothes street market. The partial results of the work concluded that the Aprazivel clothes street market has been going through the economic crisis faced in the whole country. Besides, it identified adaptations to the context of contemporary competition in the market.
\end{abstract}

Keyword: Market. Manufacture. Economy.

\section{Introduction}

This manuscript focuses on aspects of the dynamics of the Aprazível clothes street market, in the municipality of Sobral, northwestern Ceará. In this street market, many manufactures take the products they produce themselves to sell. This paper also creates ground for discussion and debate on this productive activity that generates employment and income for the population of Aprazível. Besides that, it goes over the influence on the local and regional economy.

In this context, it is worth mentioning a historical period in this street market. It used to take place at the Meruoca square - now known as Cuba square - in the business district of Sobral, a busy place conducive to this activity. However, the fact of taking place in the square displeased the local shopkeepers. Araújo points out (2013 Apud Parente, 2015, p.30) that the shopkeepers used to mention the beautification of downtown to demand the removal of the tents, promoting an urban aesthetic compatible with the modernization process that the city was going through. As a solution to this problem, Sobral city hall moved the street market to Junco, a neighborhood close to the convention center. After some local shopkeepers had mentioned a decrease in the number of customers, the city hall moved the market again. It has been working in Aprazível since 2001, which is about $25 \mathrm{~km}$ from Sobral. The Aprazível street market uses to be famous for trading products from the rural area, as Parente highlights (2015, p.28):

The market at that time used to be traditional and have rural aspects, from its structure to the products. The products sold were the following: flour, beans, corn, vegetables, fruits, animals (cattle, goat, pig, and poultry), cheese, milk, strands of tobacco, cachaça, eggs, harness for animals, knife, cake (kg), pack saddle, fabric, clay objects (pan, jar, pot), hammock.

The market mentioned by Parente (2015) had already lost strength in the local context and, it decreased in size with the arrival of the clothes market in the district. In time, this recently arrived market was changing and incorporating other elements and opening hours. Profit used to vary, and it had common problems of any other economic activity. With the creation of the Associação dos Feirante de Aprazível (Association of Traders from Aprazível, AFA), it began to organize the market to improve conditions for both traders and customers. In time, other significant changes have occurred.

Besides having created formal and informal jobs and consequently made it possible for the generation of income, the arrival of the clothes market in Aprazível has intensely modified the local urban and rural dynamics. This fact is significant since it raises the debate about the relevance of free street markets. This manuscript works on the positive things this market has brought to Aprazível, such as the products, infrastructure, jobs, and elements

\footnotetext{
${ }^{1}$ Geographyundergradstudentat Universidade Estadual Vale do Acaraú (Acaraú Valley StateUniversity, UVA), Sobral/CE. Email: Italora35@gmail.com. Supportedbythe Conselho Nacional de Desenvolvimento Científico e Tecnológico (NationalCouncil for ScientificandTechnologicalDevelopment, CNPq).

${ }^{2}$ Associate professor in the Geography undergraduation and graduation coursesat UVA, Sobral/CE. Email: geoluiz@ hotmail.com
} 
incorporated into it since the last surveys, contributing to discussions about this economic activity and expanding the horizons on this topic.

\section{Some Highlights on the Street Market}

The street markets, especially in the northeastern regional context, are wide-ranging. Over time, the ones in northeastern Brazil stopped selling only food to include clothes. With this mixed trait, they lost at times their original essence, which is selling food, and started trading only clothes.

The ideas of Gonçalves and Holanda (2017), Correa (2014), Gonçalves (2016), Gonçalves and Tomaz Júnior (2002) shed light on the discussion of this topic. The markets played a significant role in the economy and settlement in the Northeast. Ab'Saber (2003, Apud Gonçalves and Holland, 2017, p.72) points out that some cities in northeastern Brazil emerged from them, such as Campina Grande-PB, Mossoró-RN, Crato-CE, Sobral-CE, Feira de Santana-BA, Caruaru-PE, and Garanhuns-PE. These cities, which are still relevant for their regions, had the market among their strongest economic matrices in the past because it fed back the importance of these places. Corrêa (2014, p.67) states that the more significant the city is in terms of centrality, the more significant will be the absolute importance of its fair.

However, there has been a change in the disposition of street markets, losing the role of contributing to the process of settlement of territories, but maintaining and, in some cases, increasing economic importance in the local and regional context of specific places. Besides, the market also changes concerning the origin and essence of the products traded. Advancing a little further in this discussion, Gonçalves (2016, p.28) highlights that:

Street markets have undergone significant changes in their content since the 1970s. The goods from rural areas and the inclusion of low-value industrialized items prevailed in such spaces. However, plastic items became little by little predominant over the utilitarian handicrafts, also characteristic of traditional markets.

As highlighted by the author, the goods sold on a larger scale until the 1970s were essential from rural areas. The previous decades were marked by intense migration from the countryside to big cities, especially from the northeastern to the southeastern region. It might be one of the reasons that explain the change in the characteristics of the street markets. At that time, the rural population was higher than today, about $55 \%$ in $1960,44 \%$ in 1970 , and $34 \%$ in 1980, according to IBGE. Thus, the Brazilian urbanization process forced the street markets to modify their nature. Since unemployment, hunger, poverty, and misery forced people to leave the countryside, those people started populating big cities and changing their productive function, working in informal jobs because they often did not find other means of survival. Gonçalves and Tomaz Júnior $(2002$, p.4) point out that:

Informal jobs rise as a shelter for workers with little or no qualifications for modern urban work. According to recent interpretations, it happens because there is neither possibility nor economic viability for large companies to perform specific tasks, which allows the occurrence of gaps among the economic activities.

Therefore, the street market would fill the gaps among the economic activities, providing jobs and income for the population that is not able to work formally. The vendors see in the street market an opportunity to perform direct or indirect functions related to it.

These are some notes that support this manuscript. Therefore, debating them is essential to understand the contemporary dynamics of the markets. However, this debate must consider recent issues that have arisen over time and have caused many modifications to them.

\section{Material and Methodology}

This research, which is still in its development stage, is based on literature review, documentaries, and fieldwork in an attempt to understand this broad topic, given the modifications that the northeastern markets have undergone over the years. As this report is not complete yet, given the stage the research is at, there will still be the application of questionnaires and interviews whose date will compose a database where the most relevant information undergoes a systematization to assist further works and the final report.

\section{Results and Discussion}

The vendors and customers consider the Aprazível clothes market in Sobral-CE to be the largest one in the countryside of Ceará. On Fridays, it gathers around 650 vendors and thousands of customers from everywhere in Ceará, especially from municipalities in the northeastern and northern regions. The fieldwork was enough to find out the large number of people who travel long distances to reach this place. The people present at that day were from thirty-four different cities, namely Canindé, Cariré, Cascavel, Coreaú, Eusébio, Forquilha, Fortaleza, Groaíras, Guaraciaba do Norte, Ipu, Itapajé, Itapipoca, Itarema, Jijoca de Jericoacoara, Maracanaú, Martinópole, Meruoca, São Benedito, Sobral, Tianguá, Viçosa do Ceará and Uruburetama. 
In front of the market, there were cars with plates from other municipalities in the Northeast and North regions. Those people came from the cities of Caicó-RN, Serra Negra do Norte-RN, Caraíbas do Piauí-PI, Esperantina-PI, Parnaíba-PI, Teresina-PI, Magalhães de Almeida-MA, and Santana-AP. Thesedata demonstrate that the Aprazível clothes marketis capable of linking locally, regionally (the mesoregions of Ceará and the North-Northeast).

The affordability delivered by the highway (BR-222) explains the connection with different places in Ceará and out of it.This highway plays a significant role in the logistics of vendors and customers and the arrival and disposal of goods. Gonçalves and Amora (2013, p.9) highlight that:

[...] not by chance, the Aprazível clothes market is on the banks of the highway BR-222, close to the junction with busy roads (CE-364, CE-321, and CE-183). For this reason, it was possible to expand the sales and consumption relationship to other municipalities in the countryside.

In this sense, the change of the place where it used to take place until the mid-2000s was not a thoughtless act, but a masterstroke that expanded the range of the Aprazível market to municipalities that did not have access to it. Friedmann and Alonso (1964, p.1 Apud SOUZA, 2009, p.2) point out that the decision of where to locate a project is as important as the project itself. Thus, this displacement increased the flow of people and sales, implying an increase in profits and consequently in the generation of employment and income, although the vast majority are informal.

\subsection{Aprazível Street Markets Has Got A Little Bit of Everything}

When entering the Aprazível market, it is impressive the diversity of products found there. Some tents sell rough products such as belts, leather hats, and handmade hammocks (they usually serve only one specific type of customer).Others sell industrialized products such as socks, underwear, bras, swimwear, towels, shorts, and t-shirts. Over the years, the market has gone through many metamorphoses that have led to its current configuration. However, the peculiar feature of the northeastern old street markets, which is the commercialization of food products that makes the field-city connection still present. Besides, there are those typical tents of the popular northeastern street markets, which were remarkable in the past and that now have lost space, sharing the same area with clothes tents and taking advantage of their customers. In this place, it is possible to find products a wide range of food products, such as jackfruit, mango, pumpkin, beans, carrot, banana, passion fruit, sweet potato, tomato, cassava, and the old and good homemade cachaça.

Figures 1 and 2 - Fruit, and handmade and industrialized products tents, respectively
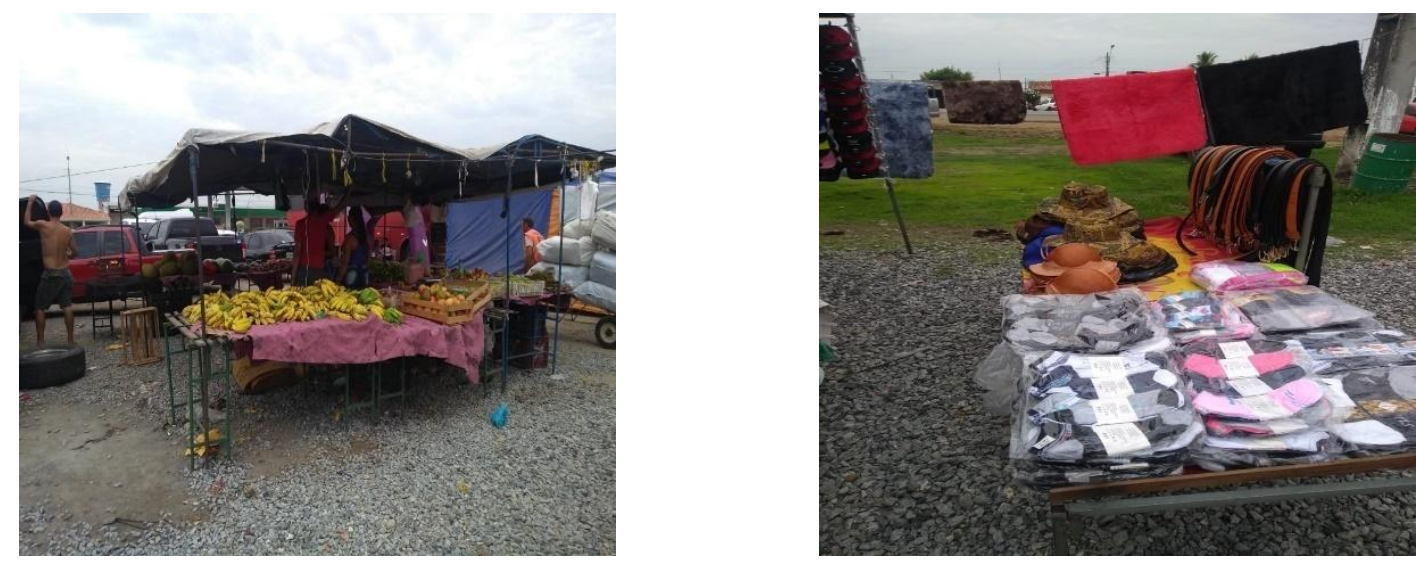

Source: Silva; Gonçalves (2020).

\subsection{The Aprazível Market and Its Neighbor}

Fieldwork always assiststhe observation of the dynamics of society and is necessary for specific actions, above all, to carry out research that shows results that come from reality. In January 2020, one could notice the construction of a mall about $40 \mathrm{~m}$ away from where the Aprazivel market is, the NOMADMALL mall. This construction, something recent in the context of the Aprazível market, presents itself in a significant way because it brings to light a fact that Parente (2015) and Gonçalves (2016) could not report in their researches. Gonçalves (2016, p.255) already pointed to the insertion of public street markets in private spaces, the malls. He said that the agglomeration would now take place in private commercial establishments that are nothing more than sheds with hundreds of boxes or commercial spaces for the vendors that were in the street market. The question was that this debate did not involve the Aprazível market because, at that time, it was unlikely that a mall could be built in the vicinity and thus stealits customers and vendors. 
Figures 3 and 4 - NOMADMALL billboard and the construction of the mall, respectively.
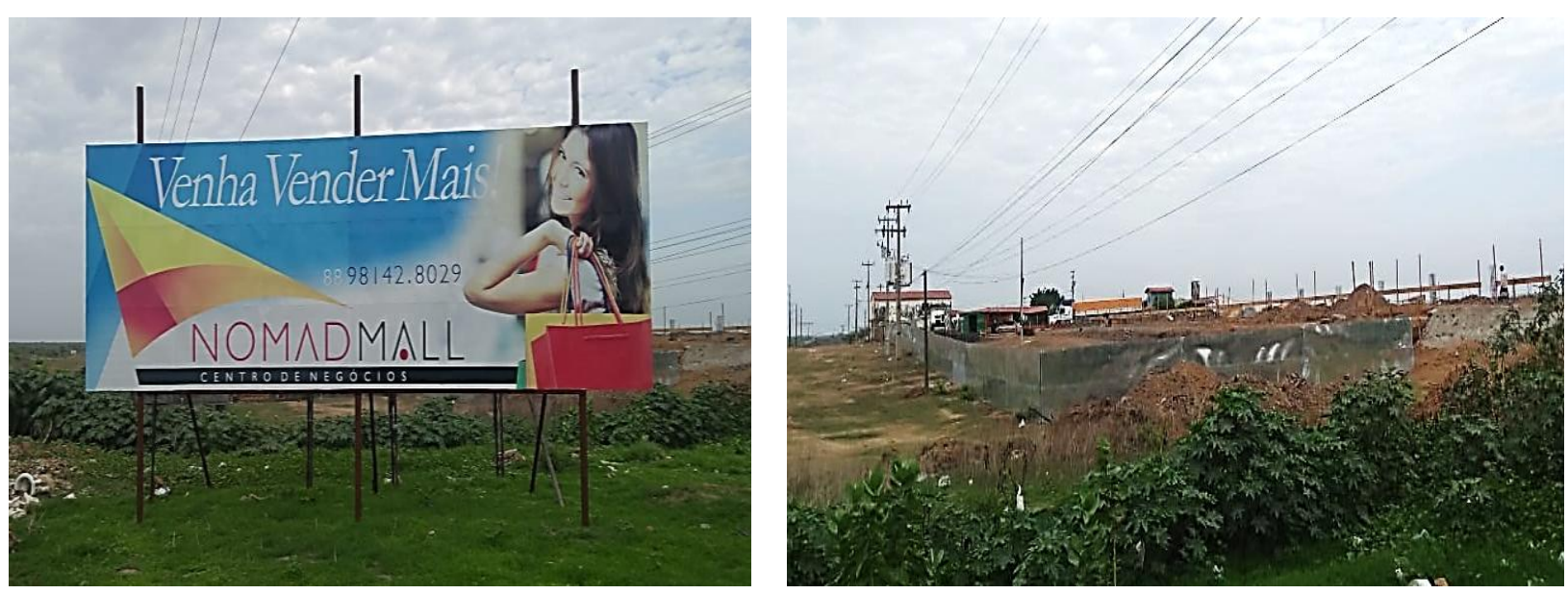

Source: the authors, 2020.

However, there is a puzzling factor in the installation of this mall near the Aprazívelmarket. In general, Gonçalves (2016) points out that these enterprises seek to solve problems related to the planning and organization of the street market, which by chance, generate impasses and conflicts regarding the functioning of the traffic and the location.

The discussions are usually about the withdrawal of the market to other urban zones, which, for managers, do not interfere with the dynamics of the city. The opinions in favor or against the permanence of the market in downtown mobilize various social agents, from the vendors, which started to organize themselves in associations, to class entities, such as landowners, real estate promoters, and public power. The option raised almost always comes captained by private enterprise construction projects to welcome the vendors outside downtown (GONÇALVES, 2016, p.255).

However, this is not the current situation of the Aprazivel market, and the issue is not even the infrastructure of the place, a subject addressed in the next section. According to an AFA member, the construction has no relation with the Aprazivel market since the changing of places would increase costs due to the payment of fees that vendors must pay to keep atent inside this building. In addition to this cost, there are also the ones concerning transportation, food, water, electric power, among others.

Some believe that such a construction close to the Aprazivel market seeks to attract more sophisticated and demanding customers. Also, that it would host local, regional, and national famous brand stores and, therefore, it would move money values higher than the one in the Aprazíve lmarket.

\subsection{Recent Factors in the Aprazível Market Infrastructure}

No needed to be a regular visitor to these street markets, whether they sell food or clothes, to know that their infrastructure conditions are precarious and often unhealthy. Wooden tents covered with canvas and chemical toilets are two examples of the lack of infrastructure in these places.

However, the Aprazível market shows a different aspect when compared to others in terms of infrastructure and service provision. It can offer conditions almost similar to those found in Brazilian business districts, without being limited to this space and without losing the features of a street market. There, one can find an ample and safe parking lot, comfortable bathrooms, a first aid ambulatory with a professional person always ready for providing the necessary services, free internet, legal advice, and security guards. It is worth mentioning that in this context, the compared services concern the Aprazível and Moda Center Santa Cruz (Capibaribe-PE) street markets. Gonçalves (2016, p.257), when talking about Moda Center Santa Cruz, highlights:

According to data from 2015 , there are 9,624 boxes $(2 \times 1 \mathrm{~m})$ divided into six modules, 707 stores, and infrastructure with six food courts in a covered area of 120 thousand square meters $\left(\mathrm{m}^{2}\right)$. Besides, it also counts on various services, such as housing for drivers, ambulatory, ATMs, shopping carts, sound system, TV, security cameras, customer service, and wireless internet. There is also a parking lot with 6,000 spaces for cars and 500 spaces for buses.

Thus, the Aprazível market does not follow the Brazilian pattern that is offering good-quality services in a mall, just like in Santa Cruz do Capibaribe. Aiming at attracting more people, AFA has signed a partnership with bus 
companies to assist the cost of bus fuel coming from other states, besides offering accommodation for these people. After acquiring a plot of land close to the market, AFA intends to build a hotel containing 30 apartments to serve and attract more customers and vendors.

Far from these patterns, the Aprazível market has some similar elements and thus manages to maintain the status of the largest fair in the countryside of Ceará, another reason for not moving it to the mall.

\subsection{Working at Aprazível Street Market}

The market is an informal universe, and its assumption almost always impacts on the quality of the service, that is, poor working conditions. However, it is worth mentioning that it also has formal traits, such as the security guards, the person who provides medical care, the caretakers, and the electrician. These are the ones offered by AFA, without mentioning others that it generates indirectly. However, the informal occupation is the one that moststands out due to its amount. Gonçalves and Tomaz Junior (2000, p.2) state that the capitalist production reorganization generates a significant number of workers forced to accept poor working conditions, such as low salary, no labor rights, long working hours, among others.

An informal occupation with poor working conditions is the people who work carrying the wares all day, requiring much physical effort on their part. However, it is the only way they find to acquire income. Parente (2015, p.64),alluding to the Aprazível market, points that those people arrive at the parking lot where the buses of the vendors are and take the products to the tents, receiving $\mathrm{R} \$ 5.00$ for each transported bag.

In times when informal occupations are growing in the country, one can even make an analogy of these people with motorcycle couriers, who usually earn R $\$ 5.00$ for each delivery they do. Nowadays, this kind of service is called entrepreneurship by the neoliberal discourse in vogue in Brazil. The expelling of these workers from the formal market along with the extreme need for survival, as highlighted by Tomaz Júnior (2000 Apud Gonçalves and Tomaz Jr, 2002, p.6):

The current social context comes from the combination of production reorganization and neoliberalism. Thus, workers from all over the world suffer debasement when they have their labor rights deprived since the government policies fail to give them the proper protection. Besides, it also happens when they leave the formal market to live in poor working conditions marked by the informality.

If the fair is an informal universe, would it be correct to say that it is an activity that grows a lot in the current national economic moment? Not at all. And this was verified in fieldwork when observed that the market decreased in size without losing force.

The Aprazivelmarket depends on how good the economy is to get significant profit and, despite the informal nature, to generate employment and income. But, more than informality, it is the reflection of the national economy in the local and regional context.

Figure 5 - The area where the tents used to be until 2016 is currently a parking lot, as seen in the back.

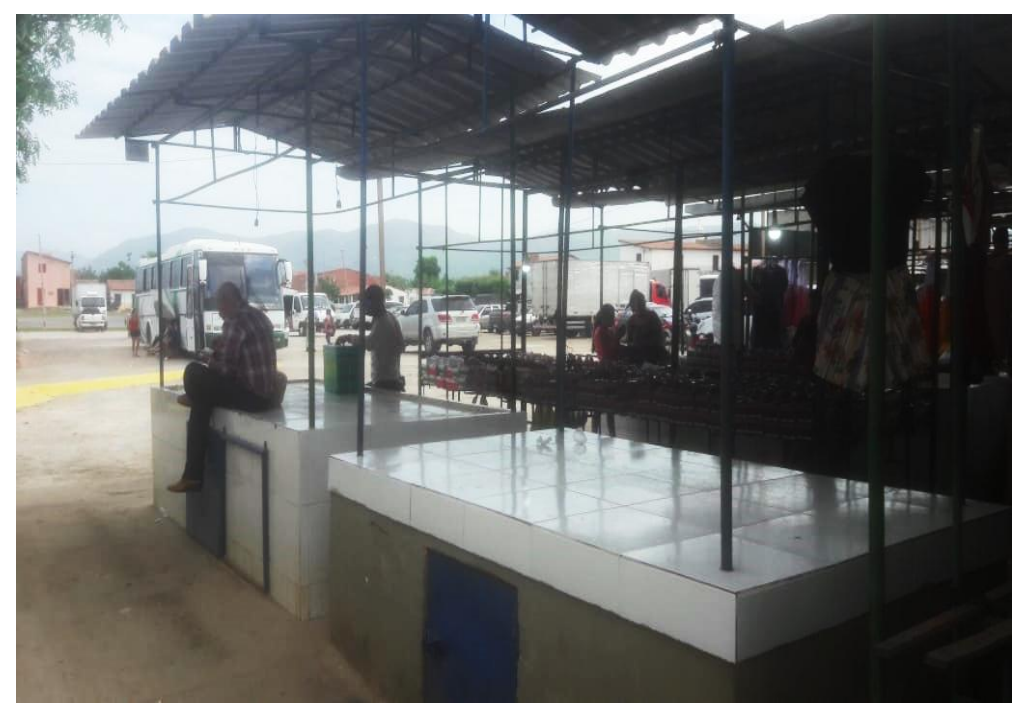

Source: the authors, 2020. 
If people are busy generating income, then themarket is going well. Superfluous actions and activities, such as buying clothes and beauty cosmetics, and spending on gyms, are left in the background.The priority is for essential stuff, such as food, water, electricity bills, rent, among others. With all sectors affected, the consequence is the decrease in production and salesdue to the demand, and consequently, unemployment.

\section{Conclusion}

This research sought to understand the current dynamics of the Aprazível street market in Sobral-CE, considering aspects like the products, structure, and work. Since this paper is still under construction, it has not yet been able to bring complete results concerning the topic.

This paper also serves as a support for discussions concerning factors that are now part of the markets, especially the one in Aprazível. Therefore, this debate and studies must continue to make the discussion of this relevant issue evolve, both locally and regionally.

\section{Acknowledgment}

Conselho Nacional de Desenvolvimento Científico e Tecnológico (National Council for Scientific and Technologica IDevelopment, CNPq)

\section{Reference}

CORRÊA, Roberto L. Trajetórias geográficas. 7 ed. Rio de Janeiro: Bertrand Brasil, 2014.

GONÇALVES, Luiz Antônio A. A metamorfose das feiras nordestinas com a inserção da confecção popular:estudo geográfico das Feiras de Caruaru-PE; Aprazível, Sobral-CE e Serrinha-BA. 327 f. 2016. Tese (Doutorado em Geografia) - Programa de Pós-Graduação em Geografia, Universidade Estadual do Ceará, Fortaleza, 2016.

GONÇALVES, Luiz Antônio A.; AMORA, Zenilde B. O papel da rede rodoviária na difusão geográfica das feiras de Confecção do Estado do Ceará, Brasil. In: ENCUENTRO DE GEÓGRAFOS DA AMÉRICA LATINA - EGAL, 14., 2013. Anais ... Lima, Perú, 2013.

GONÇALVES, Marcelino A.; THOMAZ JUNIOR, Antonio. Informalidade e precarização do trabalho: uma contribuição a Geografia do Trabalho. Geografía y CienciasSociales. V. 1.. n. 119 (31), p. 1-15, 1 ago. 2002.

PARENTE, Analine M. M. Se o novo já é velho, imagine o antigo? Formação e territorialidade da feira livre do Aprazível, Sobral (CE). 91 f. Dissertação (Mestrado em Geografia) - Mestrado Acadêmico em Geografia, Universidade Estadual Vale do Acaraú, Sobral, 2015.

SOUZA, Nali de Jesus de. Desenvolvimento Regional. São Paulo: Atlas, 2009. 